\begin{abstract}
Iranica
Abstracta Iranica Revue bibliographique pour le domaine irano-aryen

Volume 34-35-36 | 2017

Comptes rendus des publications de 2011-2013
\end{abstract}

\title{
Tomris Bakir. Dascylium (547-334 B.C.)
}

\section{Astrid Nunn}

\section{(2) OpenEdition}

\section{Journals}

Édition électronique

URL : http://journals.openedition.org/abstractairanica/41676

DOI : 10.4000/abstractairanica.41676

ISSN : 1961-960X

Éditeur :

CNRS (UMR 7528 Mondes iraniens et indiens), Éditions de l'IFRI

\section{Référence électronique}

Astrid Nunn, «Tomris Bakir. Dascylium (547-334 B.C.) », Abstracta Iranica [En ligne], Volume 34-35-36 |

2017, document 79, mis en ligne le 15 juillet 2016, consulté le 27 septembre 2020. URL : http://

journals.openedition.org/abstractairanica/41676; DOI : https://doi.org/10.4000/abstractairanica.

41676

Ce document a été généré automatiquement le 27 septembre 2020.

Tous droits réservés 


\title{
Tomris Bakir. Dascylium (547-334 B.C.)
}

\author{
Astrid Nunn
}

\section{RÉFÉRENCE}

Tomris Bakir. « Dascylium (547-334 B.C.) », in : Orhan Bingöl, éd., Ord. Prof. Dr. Ekrem Akurgal 100 Yaşında. Ankara University, Faculty of Letters, 2012, p. 1-30. (Festschrift Series Supplements III.1)

1 Parmi les articles parus dans les mélanges pour honorer le centième anniversaire du grand archéologue classique turc Ekrem Akurgal (1911-2001) un seul traite un thème achéménide. Il s'agit d'un résumé des fouilles de 1988 à 2008 à Daskyleion, où E. Akurgal avait lui-même travaillé de 1954-1960. Ce site est surtout connu pour son architecture et ses bulles d'époque achéménide, pour lesquelles les fouilles récentes pourraient avoir précisé le bâtiment dans lequel elles scellaient les documents. Un nouveau bâtiment bien construit et accompagné d'installations cultuelles est interprété comme un sanctuaire zoroastrien. Des monnaies et des centaines de tessons attiques ont de nouveau été retrouvés sur le site.

\section{AUTEURS}

\section{ASTRID NUNN}

Université de Munich 